\title{
AYELET BANAI International Injustice: Past and Present
}

\author{
Daniel Butt, Rectifying International Injustice: Principles of \\ Compensation and Restitution Between Nations, \\ Oxford University Press, 2009.
}

Suppose you are a citizen of a former colonial power. You think colonialism was wrong and consider yourself a genuine sympathizer of the national liberation movements and anti-colonial struggles of the nineteenth and twentieth centuries. Due to these wrongs of the past - as claim various activists, academics, associations and state-officials today - you may well still have duties towards present-day citizens of former colonies. Well, do you? Daniel Butt makes a very valuable contribution to answering this question in his carefully argued, thoughtprovoking and pleasant-to-read book. Not only does he assess claims to rectify historic wrongdoing in light of broader understandings of distributive justice, but he also offers an original and insightful perspective on the disagreements between what have often been labelled 'cosmopolitan' and 'statist' theories of international justice by drawing a distinction between forward-looking and backward-looking accounts of just distributions. Present-day nationals of former colonial powers, it emerges from this discussion, do owe duties to non-nationals as a result of harms related to colonialism, even if those were committed in a distant past. How come?

The 'rectificatory project' at the centre of the book refers to the claim that rich and formerly colonial nations owe reparation, compensation or restitution for their colonial wrongdoing, including exploitation and enslavement, to considerably less wealthy groups and nations that they had colonized. Such claims are not new and their implications for principles of distributive justice have been closely examined, with the general conclusion that within egalitarian theories of distributive justice, historical justice claims often seem pale. For those disadvantaged today, egalitarian theories yield enough reasons in the present to sustain claims for redistribution. The rather hard to establish chains of culpability, responsibility and harm across generations - inherent to historical justice claims - emerge, then, as only marginally relevant, if at all. As Butt puts it: 'For those who broadly think that the distributive game begins again in each new generation, there is no point in looking to the historic actions of previous generations to work out who it owed to whom in the present day', (p. 51). Then why worry about history? 
The reply lies in the distinction, discussed in Chapter 2, between forwardlooking and backward-looking accounts of distributive justice. Forward-looking accounts are those that require redistribution in every generation. Backwardlooking accounts - prominent among them is Robert Nozick's theory of historical entitlement - do not require such redistribution, as they do not require keeping with egalitarian patterns of holdings. That historical justice claims have appeared philosophically marginal is a result of the forward-looking perspective, which redistributes in every new generation and which is dominant among philosophers on questions of domestic justice. When it comes to international justice, however, Butt observes, the picture is markedly different. Here backward-looking accounts enjoy much more support, and '...characteristically advocate principles of just international interaction which do not require redistribution across boundaries with the coming of each new generation. When one holds such a world view, the historical provenance of modern day advantages becomes crucially important (pp. 31-2).' To whom and how, then, do historical justice claims matter?

It turns out that a highly important group of positions and philosophers including, among others, John Rawls, David Miller and Michael Walzer fall under Butt's category of 'international libertarianism'. International libertarians acknowledge and endorse principles of just international interaction - including non-aggression, compliance to treaties, refrain from harm to non-nationals as well as specified duties of assistance. International libertarians do not generally consider inequalities between nations as such as giving rise to concerns of justice, with the exception of those resulting from 'wrongful harms, defined in terms of violations of the principles of just international interaction' (pp. 98-9). Evidently, the present-day holdings of different nations have been acquired by frequent and severe violations of these principles. For international libertarians and their backward-looking account of justice, rectifying such wrongdoings should matter a great deal. However, the passing of time and generations gives rise to further challenges to the claims of the rectificatory project regarding colonialism. It is not clear that anyone can still make a case that they suffer harm by centuries old events, and it is not clear that claims to stolen property that may have been previously justified have not lapsed. Can these objections be met?

In Chapters 4 and 5 of the book, Butt develops two ways of identifying the extant injustice resulting from the wrongdoing of previous generations. One applies the principle of compensation for harm; the other works within the premises of restitution of property to those entitled to it. Whereas the argument from harm is somewhat inconclusive, the argument from historical entitlement opens a truly promising perspective for theories of international justice. The discussion of compensation for harm (Chapter 4) addresses a group of objections which 
doubt that people today can claim that they have been harmed by events in the distant past. A noteworthy argument responding to these objections is the one that questions the counterfactual accounts employed in them. Counterfactuals are inherent to harm-claims, but in the case of colonialism, it is suggested, the relevant counterfactual story is not one in which the harmful action had been avoided, but rather one in which interaction had been fair.

The discussion of the inheritance and restitution model (Chapter 5) includes a contentious and appealing suggestion that a theory of historical entitlement to property rights makes (some) sense in the international context. Central objections to redressing historical injustice through restitution are 'dependent upon the idea that historical entitlement theory is intrinsically flawed' (p. 147). This, however, the argument continues, is a result of the individualistic premise of a Lockean theory of acquisition. "If we replace the foundational unit of historical entitlement theories and speak of the entitlement of collectives rather than individuals, a host of problems associated with the domestic variant of the argument disappear' (p. 147). International libertarians, then, are in a position to tell a story about collectives that had acquired entitlement to property, and argue against some of the current cosmopolitan positions that they violate such legitimate entitlements. This requires that we accept the proviso, in line with current norms of international law, that states have the right to exclusive use of the resources in their territories, and that some account can be provided as to how states legitimately come to acquire their territories (p. 153). Be that as it may, under the very same international libertarian position, the rectificatory claims gain ground, as the entitlement to the property that had been misappropriated by others persists.

To the cosmopolitan reader this argument may appear as an insurmountable objection to international libertarianism, committing that position to a suspicious theory of property rights and to a controversial claim that states have the right to exclusive use of the resources in their territories. The international libertarian reader could then point out that cosmopolitans, too, endorse the idea that some territorial political units should exist with some rights of self-government, without, so far, providing a persuasive account of why and how - on cosmopolitan terms - this should come about. Butt himself, it should be noted, does not endorse international libertarianism. Rather, the motivation for exploring the strengths and implications of a position which one wouldn't ideally support lies in the importance and acceptance of this position both among philosophers and in international law and 'real politics'.

For the purpose of the book, the aspiration to take real existing political argument seriously is commendable - not as source of moral truth, but as 
something that philosophical argument needs to deal with. Taking this aspiration seriously, however, may open at least one point in the philosophical argument of the book to doubt. The point concerns the question whether and why is it meaningful to submit historical actions to retroactive moral judgment. The question is important for rectificatory claims in regard to colonialism because if conquerors and colonizers had been acting in line with the accepted principles of international interaction of their time, it might be mistaken to judge them unjust by applying present-day criteria of just international interaction. Butt proposes a helpful solution by distinguishing between judgment of the actors and judgment of the actions. If individuals failed to act according to moral standards that could not have been known to them, we might suspend judgment on their moral qualities as individuals or groups. This, nevertheless, does not render the action - say the institution of slavery - any less susceptible to being judged as unjust. Without endorsing moral relativism, it is argued, we cannot subsume morality under what people happened to believe morality was. This solution take us this far - far enough for the rectificatory project discussed in the book - but it immediately gives rise to a more fundamental question: do we really have access to principles of morality independent from the judgments and beliefs of people? When we assert that an act is unjust we still employ a human beings' judgment about morality.

Moral relativism is not implied in the observation that the principle according to which the institution of slavery is - and possibly always has been - unjust is reached through, and substantiated by, reference to the moral judgments of human beings. This means that to judge unjust the wrongdoing related to colonialism - dispossession, exploitation or enslavement - we would be on a much safer ground by noticing the contentiousness of these actions at the time and the opposition to them, exhibited clearly, but not exclusively, among those exploited, enslaved and dispossessed. Taking such historic debates and struggles seriously would not as such yield unequivocal principles of justice, but would at least provide a more meaningful ground for critique, than a shrug coupled with the claim that, fortunately, we simply know better.

Ayelet Banai

Goethe University - Frankfurt am Main

Email:banai@soz.uni-frankfurt.de

the globaljusticenetwork 